\title{
Effects of colony stimulating factor-1 on human extravillous trophoblast growth and invasion
}

\author{
G S Hamilton, J J Lysiak, A J Watson ${ }^{1}$ and P K Lala \\ Department of Anatomy and Cell Biology and ${ }^{1}$ Physiology, The University of Western Ontario, London, Ontario, Canada N6A 5C1 \\ (Requests for offprints should be addressed to P K Lala, Department of Anatomy and Cell Biology, Medical Sciences Building, The University of Western \\ Ontario, London, Ontario, Canada N6A 5C1)
}

\begin{abstract}
Colony stimulating factor (CSF)-1 has been localized in a variety of tissues and shown to influence proliferation and differentiation of numerous cell types. Messenger RNA and protein products of CSF-1 and its receptor (c-fms) have been identified in the human placenta and decidua. We examined whether CSF-1 and c-fms mRNA and protein are expressed by normal human first trimester invasive extravillous trophoblast (EVT) cells propagated in culture and whether CSF-1 influences proliferation and/or invasion of these cells. CSF-1 mRNA and protein expression was determined by RT-PCR and immunofluorescence microscopy. Proliferation was assessed by the cellular uptake of tritiated thymidine and invasion was evaluated by Matrigel invasion assay as well as Northern blot analysis of mRNA expression for invasion-associated enzymes and their inhibitors. Results revealed that normal invasive EVT cells in culture express both CSF-1 and c-fms mRNA and protein. Under serum-free conditions,
\end{abstract}

exogenous CSF-1 greatly stimulated the proliferation of these cells. CSF-1 neutralizing and c-fms receptor blocking antibody $(\mathrm{Ab})$ each abolished the growth stimulatory effects of CSF-1, indicating that CSF-1 and c-fms interaction was responsible for these effects. In fact, $\mathrm{c}-\mathrm{fms} \mathrm{Ab}$ alone reduced proliferation to below background levels. While exogenous CSF-1 failed to influence EVT cell invasiveness, Northern blot analysis of mRNA indicated a slight upregulation of the invasion-associated enzyme $72 \mathrm{kDa}$ type IV collagenase as well as its natural inhibitor tissue inhibitor of metalloprotease (TIMP)-1, so that the balance between the two remained unaltered. These findings suggest that CSF-1 may represent an autocrine (and possibly paracrine) growth stimulatory factor for the invasive trophoblast cells in situ with no net effect on their invasiveness.

Journal of Endocrinology (1998) 159, 69-77

\section{Introduction}

Trophoblast growth and invasion of the uterus are essential events in human pregnancy. While these events ultimately create an interface for efficient exchange of molecules between fetal and maternal circulations, trophoblast invasion must remain a stringently regulated process in order to prevent destruction of the uterus. The optimal extent of trophoblast invasion and its transient nature are believed to result from paracrine and autocrine systems involving the trophoblast and the maternally-derived decidua into which the trophoblast invades (reviewed by Lala \& Hamilton 1996). A number of growth factors produced at the fetomaternal interface have been shown to influence trophoblast proliferation and invasion. For example, transforming growth factor (TGF) $\beta$ reduces the extents of both proliferation (Graham et al. 1992) and invasion (Graham \& Lala 1991, 1992) by human invasive trophoblast in culture whereas epidermal growth factorreceptor (EGF-R) ligands (EGF and TGF $\alpha$ ) enhance the proliferation by these cells without significantly affecting their invasiveness (Lysiak et al. 1993, 1994). Another EGF-R ligand, amphiregulin, also stimulates trophoblast growth (Lysiak et al. 1995).

Colony stimulating factor (CSF)-1 is a homodimeric glycoprotein which is produced in a variety of adult tissues (reviewed by Sherr \& Stanley 1990) and which has been shown to modulate proliferation, differentiation, and survival of numerous cell types (Stanley et al. 1983). Patterns of expression of CSF-1 and its receptor (c-fms), which possesses intrinsic tyrosine kinase activity, suggest that this is another factor with potentially important roles in regulating trophoblast functions.

Studies in mice revealed that uterine concentrations of CSF-1 increase approximately 1000-fold during pregnancy and that there is a concomitant increase (about 100-fold) in CSF-1 mRNA in the luminal and glandular epithelium (Bartocci et al. 1986, Pollard et al. 1987). Similarly, in the human, extractable immunoreactive CSF-1 protein level was found to be much higher in the pregnant than in the nonpregnant endometrium, and high in the placenta throughout pregnancy (Kauma et al. 1991, 
Daiter et al. 1992). Immunohistochemical examination revealed the presence of CSF-1 in the uterine glandular epithelium, vascular endothelium, and villous as well as extravillous trophoblast (EVT) cells of the placenta (Daiter et al. 1992). In addition, the expression of CSF-1 mRNA (identified by Northern blotting) was noted in the placenta and the decidua but not in the nonpregnant endometrium (Saji et al. 1990, Kauma et al. 1991, Daiter et al. 1992). Although immunoreactive CSF-1 receptor (the product of the c-fms proto-oncogene) was found in both the villous and EVT cells (Pampfer et al. 1992), EVT cell columns exhibited the strongest localization (Pampfer et al. 1992, Jokhi et al. 1993). The mRNA of c-fms has also been detected in the human placenta and the decidua, its expression increasing with gestational age (Saji et al. 1990, Pampfer et al. 1992). In fact, Pampfer et al. (1992) have described a trophoblast-specific transcription of exon 1 of the c-fms gene using RT-PCR. EVT cell columns were shown to be the chief location of $\mathrm{c}$-fms expression in situ (Jokhi et al. 1993). The presence of CSF-1 and c-fms mRNA and protein at the human fetomaternal interface suggest that CSF-1 may be involved in autocrine and/or paracrine interactions which may regulate trophoblast and/or decidual cell function. Therefore, in the present study, we have examined the expression of CSF-1 and c-fms in human invasive EVT cells propagated in culture as well as the potential role of CSF-1 on their proliferative and invasive abilities.

\section{Materials and Methods}

\section{Establishment of first trimester human extravillous trophoblast cell cultures}

Human first trimester EVT cell cultures were established according to the procedure described earlier from this laboratory (Graham et al. 1992, Irving et al. 1995). Briefly, chorionic villi were collected from elective terminations of first trimester pregnancy in accordance with the locally established ethical review procedures and rinsed in cold RPMI-1640 medium (Grand Island Biological Company (GIBCO), Grand Island, NY, USA). Villi were then mechanically minced and washed in medium, and the villus fragments were cultured as explants in complete medium (RPMI-1640 containing 10\% fetal calf serum (FCS), $200 \mu \mathrm{g} / \mathrm{ml}$ streptomycin, $200 \mathrm{U} / \mathrm{ml}$ penicillin and $0.50 \mu \mathrm{g} / \mathrm{ml}$ amphotericin). After $2-3$ days, nonadherent explants and cells were removed and discarded and the remaining adherent explants and cells were expanded for 1-2 weeks prior to passage and characterization. Only the cultures containing $100 \%$ cytokeratin positivity at second and later passages were retained.

Characterization of expanded and passaged trophoblast cell cultures with numerous markers was performed as described earlier (Graham et al. 1992, Irving et al. 1995). Prior to each experiment, cells were routinely immuno- stained for cytokeratin to ensure that $100 \%$ of the cells were cytokeratin positive. This confirmation was very important, since morphology alone was an unreliable guide for cell identity. In addition, as reported earlier (Irving et al. 1995), concomitant phenotyping revealed that these cells were immunoreactive for class 1 human leukocyte antigen (HLA) framework Ag W6/32 (100\%), insulin-like growth factor (IGF)-II peptide, and $\alpha_{1}, \alpha_{3}, \alpha_{5}, \alpha_{\mathrm{v}}, \beta_{1}$ integrin subunits and the vitronectin receptor $\alpha_{\mathrm{v}} \beta_{3} / \beta_{5}$. Furthermore, HLA-G mRNA and protein were expressed by these cells when grown on laminin or Matrigel (G Aboagye-Mathiesen \& P K Lala, unpublished observations). They were negative for 63/D3 (macrophage marker), Factor VIII (endothelial cell marker) and $\alpha_{6}, \beta_{4}$ integrins (villous cytotrophoblast markers). This phenotypic profile was that of invasive EVT cells in situ. In vitro propagated first trimester EVT cells (cell lines designated as HTR) were utilized at second to sixth passage.

\section{Immunofluorescence microscopy}

EVT cells were placed in 4-well chamber slides (Nunc/ GIBCO BRL) containing complete medium and allowed to attach overnight. Cells were then fixed in $4 \%$ paraformaldehyde for $30 \mathrm{~min}$, washed with PBS ( $\mathrm{pH} 7 \cdot 4)$ and incubated $1 \mathrm{~h}$ in PBS containing 10\% normal goat serum to block non-specific Ab binding. The fixed cells were then exposed to one of three primary $A b$ raised against: cytokeratin (CAM 5.2; mouse monoclonal; Becton Dickinson, San Jose, CA, USA; $25 \mu \mathrm{g} / \mathrm{ml}$ ); CSF-1 (rabbit polyclonal; Genzyme/Intermedico, Markham, ON, Canada; $10 \mu \mathrm{g} / \mathrm{ml}$ ); or c-fms (rat monoclonal; Oncogene Science/Cedarlane, Hornby, ON, Canada; $10 \mu \mathrm{g} / \mathrm{ml}$ ) and incubated overnight at $4{ }^{\circ} \mathrm{C}$. Following three $15 \mathrm{~min}$ washes with PBS, cells were exposed to fluorescein-tagged secondary antibody $(\mathrm{Ab})$ (goat anti-mouse for cytokeratin, goat anti-rabbit for CSF-1 and goat anti-rat for c-fms) for $1 \mathrm{~h}$. After three 15-min PBS washes, chambers were removed and mounting media containing Hoechst's dye (nuclear fluorescent stain) and cover slips were applied. Negative controls were exposed to similar concentrations of immunoglobulin or serum of the respective species instead of the primary $\mathrm{Ab}$.

\section{Reverse transcription-polymerase chain reaction (RT-PCR)}

Total cellular RNA was collected from subconfluent cultures of EVT cells using TRIZOL (GIBCO) reagent according to manufacturer's instructions. Complimentary DNA (cDNA) was synthesized from the total RNA using Moloney murine leukemia virus reverse transcriptase (RT, $20 \mathrm{U} / \mu \mathrm{g}$ RNA) in a RT buffer containing $0.2 \mathrm{mM}$ random primers, $12 \mathrm{mM}$ Tris- $\mathrm{HCl}, 75 \mathrm{mM} \mathrm{KCl}, 35 \mathrm{mM}$ $\mathrm{MgCl}_{2}, 15 \mathrm{mM}$ dithiothreitol, $40 \mu \mathrm{g} / \mathrm{ml}$ acetylated BSA, and $700 \mu \mathrm{M}$ each of four deoxyribonucleotide triphosphates (dNTP). Following $90 \mathrm{~min}$ incubation at 
Table 1 Olgionucleotide primer sets used in PCR to amplify reverse transcribed mRNA for CSF-1 and its receptor (c-fms)

\begin{tabular}{|c|c|c|c|}
\hline & Sequence & Product size (bp) & Reference \\
\hline CSF-1 & $\begin{array}{l}\text { Upstream: 5'-ACGACATGGCTGGGCTCCCT-3' } \\
\text { Downstream: 3'-TTCTCCAGCAACTGGAGAGGTG-5' }\end{array}$ & 407 & Daiter et al. (1992) \\
\hline $\begin{array}{l}\text { c-fms } \\
\text { (set } 1)\end{array}$ & $\begin{array}{l}\text { Upstream: 5'-AGACTAGTGGCCCAGGAACTGGT-3' } \\
\text { Downstream: 3'-TAGGTGGACATACAGTTGCTAGGC-5' }\end{array}$ & 389 & Coussens et al. (1986) \\
\hline $\begin{array}{l}\text { c-fms } \\
\text { (set 2) }\end{array}$ & $\begin{array}{l}\text { Upstream: 5'-GACAGAGTGTCCAAAAGCGTG-3' } \\
\text { Downstream: 3'-GCGGTAGGTGGAGATACAGTT-5' }\end{array}$ & 589 & Pampfer et al. (1992) \\
\hline
\end{tabular}

$37^{\circ} \mathrm{C}$ and $5 \mathrm{~min}$ enzymatic denaturation at $90{ }^{\circ} \mathrm{C}$, a $5 \mu \mathrm{l}$ aliquot of the RT mixture was amplified by PCR. Reactions were performed using recombinant Taq polymerase (5 U per tube) in a PCR buffer containing $1.0 \mu \mathrm{M}$ each of three PCR primers (Table 1) with published sequences, $10 \mathrm{mM}$ Tris- $\mathrm{HCl}, 50 \mathrm{mM} \mathrm{KCl}, 1 \cdot 0-3 \cdot 0 \mathrm{mM}$ $\mathrm{MgCl}_{2}$, and $200 \mu \mathrm{M}$ each of four dNTPs. The temperature profile was $1 \mathrm{~min}$ at $94{ }^{\circ} \mathrm{C}$ (denaturation), $2 \mathrm{~min}$ at $60{ }^{\circ} \mathrm{C}$ (annealing) and $3 \mathrm{~min}$ at $72{ }^{\circ} \mathrm{C}$ (extension). After completion of the PCR amplification, products (amplicons) were electrophorezed on a $2 \%$ agarose gel and visualized by ethidium bromide staining. Double stranded DNA sequencing was performed on gel-purified amplicons using the dideoxy-mediated chain termination method with $\left[{ }^{35} \mathrm{~S}\right] \mathrm{dATP}$ and $0.5 \mu \mathrm{M}$ PCR primer. Nucleotide sequences obtained in both orientations were compared with the published human CSF-1 and c-fms sequences.

\section{Proliferation assay}

Cell proliferation was assessed by ${ }^{3} \mathrm{H}$-thymidine $\left({ }^{3} \mathrm{H}-\mathrm{TdR}\right)$ uptake following a terminal $6 \mathrm{~h}$ pulse of ${ }^{3} \mathrm{H}-\mathrm{TdR}$ to serum-starved trophoblast cells grown for $24 \mathrm{~h}$ under different experimental conditions (as specified later). Although this laboratory has employed a number of indices of cellular proliferation (including cell counting, flow cytometric measurements of DNA, colorimetric quantitation of mitochondrial enzymes and immunostaining of proliferating cell nuclear antigen) with qualitatively similar results, ${ }^{3} \mathrm{H}-\mathrm{TdR}$ incorporation has proven to be the most sensitive and reliable assay in our hands (Graham et al. 1992, Lysiak et al. 1993, 1995).

EVT cells were cultured in RPMI complete medium for $24 \mathrm{~h}$ in 96-well microtiter plates (Flow Laboratories, McLean, VA, USA) at a concentration of $10^{4}$ cells/well. The cells were then serum-starved for 3 days using $0 \cdot 2 \%$ albumin in place of $10 \%$ FCS. On the fourth day, media was removed from the wells and replaced with serum-free media containing, varying doses $(0 \cdot 5-62.5 \mathrm{ng} / \mathrm{ml})$ of CSF-1 (Genzyme/Intermedico), or CSF-1 neutralizing $\mathrm{Ab}(25 \mu \mathrm{g} / \mathrm{ml}$; Oncogene Science) or c-fms receptor blocking Ab $(25 \mu \mathrm{g} / \mathrm{ml}$; Oncogene Science). In other sets of wells, CSF-1 was included with each of the $A b$ to determine its ability to override the effects of the $A b$ on trophoblast proliferation. In a final set of wells, FCS was added to achieve concentrations of 1 or $10 \%$. Wells were loaded in quadruplicate $18 \mathrm{~h}$ prior to exposure with ${ }^{3} \mathrm{H}-\mathrm{TdR}(1 \mu \mathrm{Ci} / \mathrm{ml})$ for $6 \mathrm{~h}$. Following the $24-\mathrm{h}$ incubation period, the medium was removed and $100 \mu \mathrm{l} 0 \cdot 25 \%$ trypsin was added to each well for $15 \mathrm{~min}$. Cells were subsequently harvested with a Titertek cell harvester which deposits cells on strips of filter paper, and disrupts them with repeated distilled water washes to remove unbound water-soluble radioactivity. The filter paper strips were then immersed in scintillation fluid and $\beta$-counts were taken with a Beckman (Palo Alto, CA, USA) scintillation counter.

\section{In vitro Matrigel invasion assay}

The influence of CSF-1 on the invasiveness of first trimester EVT cells was assessed by Matrigel invasion assays (Repesh 1989) as modified by Graham et al. (1993a). Briefly, $200 \mu \mathrm{l} 600 \mu \mathrm{g} / \mathrm{ml}$ solution of Matrigel (Collaborative Research Inc., Bedford, MA, USA) in cold RPMI 1640 medium were placed on 6.5-mm diameter Transwell filters with a pore size of $8 \mu \mathrm{m}$ (Costar Corp., Toronto, ON, Canada) and air-dried for $8 \mathrm{~h}$ in a laminar flow hood. Subconfluent cultures of EVT cells were incubated in the presence of $10 \mu \mathrm{Ci} / \mathrm{ml}{ }^{3} \mathrm{H}-\mathrm{TdR}$ in RPMI 1640 plus 10\% FCS for $72 \mathrm{~h}$. Cells were then trypsinized, washed, resuspended in medium, and the number adjusted to $2.5 \times 10^{5}$ cells $/ \mathrm{ml}$. A $200 \mu \mathrm{l}$ sample of the cell suspension in the presence of $10 \mathrm{ng} / \mathrm{ml} \mathrm{CSF-1} \mathrm{was}$ placed in the upper wells. Cells in culture medium alone served as controls and treatments were carried out in triplicate. A volume of $800 \mu \mathrm{l}$ medium was added to lower wells and the transwells were then placed into the lower wells. After a 72-h incubation period, the media in the upper and lower wells was removed and placed in separate tubes. Upper wells were washed once with PBS and the wash pooled with the media removed from the upper well. To remove cells adhering to the lower well, $800 \mu \mathrm{l} 0 \cdot 05 \%$ trypsin solution in PBS were placed in the lower well with the upper chamber reinserted for $20 \mathrm{~min}$ at room temperature. The trypsin solution was then removed and the lower wells washed once with $800 \mu \mathrm{l}$ PBS and pooled with the incubation media from the lower wells. Finally, each membrane was removed from the transwells with the aid 
of a scalpel and placed with the contents of the upper chamber. Scintillation fluid was then added to each of the tubes from each transwell and $\beta$-counts were taken with a Beckman scintillation counter. The invasion index was calculated as the amount of radioactivity in the lower wells expressed as a percentage of the sum of the total radioactivity in upper and lower wells.

Northern blot analysis of the $m R N A$ levels of the invasion associated molecules (TIMP-1, TIMP-2, and $72 \mathrm{kDa}$ type IV collagenase)

Duplicate flasks of EVT cells (utilized in invasion assay) at subconfluent density were cultured overnight in the presence of CSF-1 $(10 \mathrm{ng} / \mathrm{ml})$ or no additive in complete media (RPMI 1640, 10\% FCS) prior to RNA isolation. Total cellular RNA isolated with TRIZOL (GIBCO) solution was subjected to Northern blot analysis utilizing the following cDNA probes radiolabeled with ${ }^{32} \mathrm{P}-$ $\gamma$ dCTP: human TIMP-1 cDNA probe in a pUC9 plasmid, generously provided by Synergen Corporation (Boulder, CO, USA); human TIMP-2 cDNA probe in a pGEM1 plasmid and a human $72 \mathrm{kDa}$ type IV collagenase cDNA probe (Stetler-Stevenson et al. 1989). Blots were exposed to Kodak XAR-5 film (Eastman Kodak, Rochester, NY, USA) for 18-24 h (except for blots hybridized with $92 \mathrm{kDa}$ type IV collagenase probe, which were exposed for 5 days) at $-80^{\circ} \mathrm{C}$.

\section{Statistics}

Data were analyzed using ANOVA and when appropriate, the significance of differences between treatment groups was determined using Duncan's multiple range test. Differences were considered significant at $P<0 \cdot 05$.

\section{Results}

Expression of CSF-1 and its receptor (c-fms) by human EVT propagated in culture

Immunofluorescence As is characteristic of this pure trophoblast preparation, $100 \%$ of the cells exhibited strong immunostaining when cytokeratin $\mathrm{Ab}$ was used as the primary Ab (Fig. 1A and B). Similarly, nearly $100 \%$ of cells also stained for c-fms (Fig. 1C and D) and CSF-1 (Fig. 1E and $\mathrm{F}$ ). While the extent of staining was relatively weak for CSF-1 (Fig. 1F), cells stained intensely for c-fms (Fig. 1D). Figure $1 \mathrm{H}$ illustrates a representative negative control exposed to normal rabbit serum or appropriate mouse or rat Ig in place of the primary $\mathrm{Ab}$.

RT-PCR RT-PCR using published primer sequences (Table 1) for CSF-1 (Daiter et al. 1992) and c-fms (Coussens et al. 1986) produced the predicted $407 \mathrm{bp}$ amplicon with CSF-1 primers and 389 bp amplicon with the first set of c-fms primers (Fig. 2). A second set of c-fms primers (Pampfer et al. 1992) also produced an expected $589 \mathrm{bp}$ amplicon (not shown in Fig. 2). These products were amplified using cDNAs made from first trimester placenta and EVT cells propagated in culture.

\section{Effect of CSF-1 on EVT cell proliferation}

The addition of CSF-1 to serum-starved EVT cells at $0.5-62.5 \mathrm{ng} / \mathrm{ml}$ produced a dose-dependent increase in ${ }^{3} \mathrm{H}-\mathrm{TdR}$ incorporation (Fig. 3). A significant increase was noted at $62.5 \mathrm{ng} / \mathrm{ml}(P<0.05)$ in this experiment and this stimulation was similar to that provided by the presence of 10\% FCS. These results were duplicated at two different passages of the same HTR line. In another experiment with a different HTR line, a significant stimulation was noted in the presence of CSF-1 at $12.5 \mathrm{ng} / \mathrm{ml}$ (data not shown).

The effects of CSF-1 and c-fms neutralizing antibodies on EVT proliferation

Similar to the results shown earlier, in another experiment, addition of FCS (at 1 and 10\%) showed a dose-dependent stimulation of EVT cell proliferation (Fig. 4). With 10\% FCS, the level of proliferation nearly quadrupled $(P<0 \cdot 001)$. Addition of CSF-1 at a dose of $20 \mathrm{ng} / \mathrm{ml}$ produced a 3 -fold stimulation $(P<0 \cdot 001)$. CSF-1 stimulation of ${ }^{3} \mathrm{H}-\mathrm{TdR}$ uptake was abolished by treatment with either CSF-1 neutralizing or $\mathrm{c}-\mathrm{fm}$ s receptor blocking $\mathrm{Ab}$ (Fig. 4). In fact, these antibodies alone reduced ${ }^{3} \mathrm{H}-\mathrm{TdR}$ incorporation to levels below those of controls $(P<0 \cdot 05)$. Exogenous CSF-1 did not reverse the inhibition by c-fms receptor blocking $\mathrm{Ab}$ and only partially reversed the inhibition by CSF-1 neutralizing Ab (Fig. 4). The neutralizing effects of the antibodies were specific to the CSF-1 and c-fms antigens, since an unrelated Ab of similar isotype (raised against type 1 IGF receptor) failed to alter the proliferative responses in the same EVT cell lines utilized in the present study (Hamilton \& Lala 1996).

\section{Effects of CSF-1 on EVT cell invasiveness}

When included in RPMI complete media at doses of 10-100 ng/ml, CSF-1 did not significantly alter the invasion index (compared with controls) of first trimester EVT cells in a 3-day Matrigel invasion assay $(P>0 \cdot 05$; Fig. 5). These results were reproduced using three different first trimester EVT cell lines (data not shown). However, Northern blot analysis of mRNA for the invasion-regulating molecules MMP-2 (72 kDa type IV collagenase), TIMP-1 and TIMP-2, revealed a small ( 1.5 times) but similar upregulation in the mRNA levels of both MMP-2 and TIMP-1, as measured by densitometry 

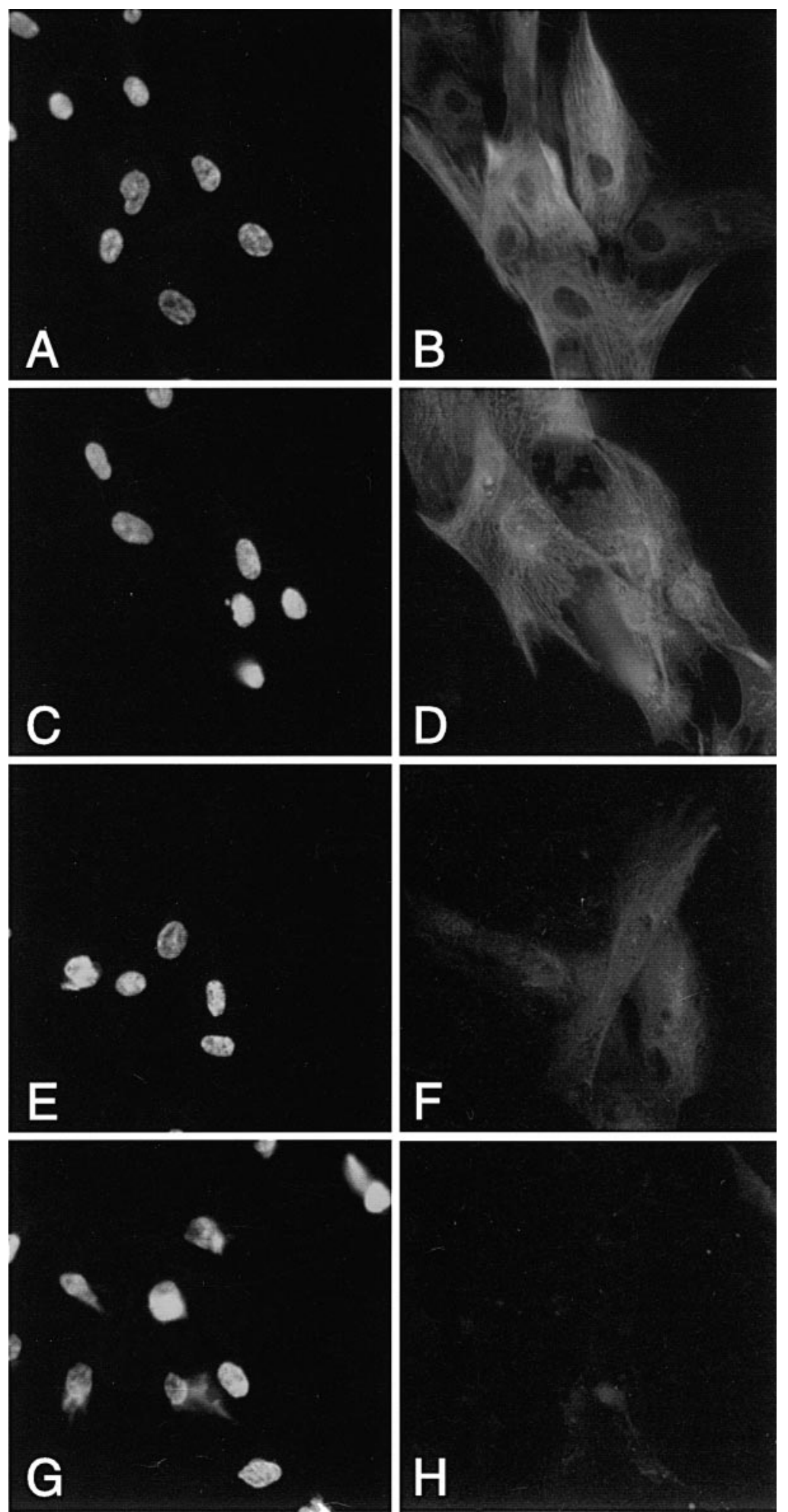

Figure 1 Immunofluorescence microscopy for human first trimester EVT cells propagated in culture. Panels A, C, E and G demonstrate positive nuclear staining for Hoechst's dye. Right panels demonstrate positive immunostaining for cytokeratin (panel B), c-fms (panel D) and CSF-1 (panel F). Panel H shows background staining characteristic of negative controls. Immunostaining is strong for cytokeratin and c-fms and less strong for CSF-1. 

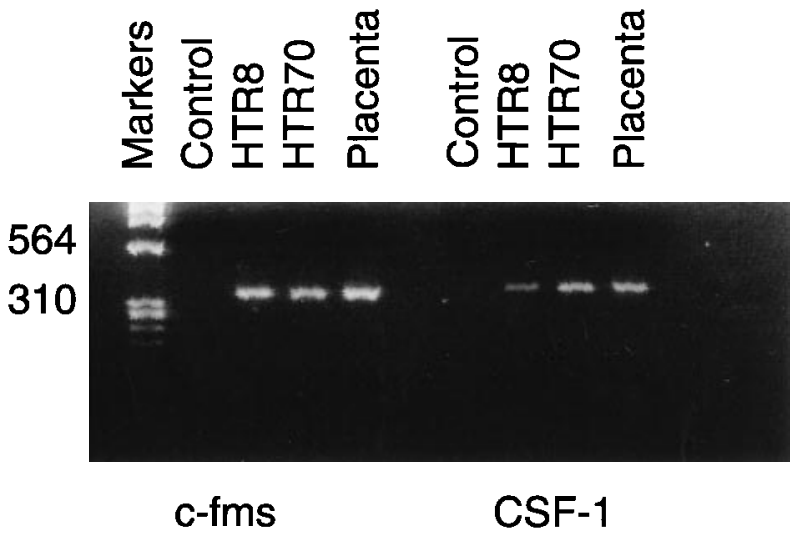

Figure 2 Agarose gel displaying amplicons resulting from RT-PCR of RNA from cultured human EVT cells (HTR8 and HTR70) and from first trimester whole placental tissue. Results indicate that both CSF-1 and c-fms mRNA are present in human first trimester placenta and extravillous invasive trophoblast propagated in culture. Molecular marker sizes are indicated as base pair numbers.

after normalization for loading against $18 \mathrm{~S}$ rRNA, whereas TIMP-2 mRNA levels remained unchanged (Fig. 6).

\section{Discussion}

The mRNA of CSF-1 (Saji et al. 1990) as well as that of its receptor, the c-fms proto-oncogene (Saji et al. 1990,
Pampfer et al. 1992, Jokhi et al. 1993), have been identified in the human placenta. In addition, in situ expression of c-fms mRNA (Jokhi et al. 1993) as well as immunohistochemical staining for the $\mathrm{c}-\mathrm{fms}$ protein (Pampfer et al. 1992) has been localized to the EVT cells. The cells used in the present study have been extensively characterized and found to possess the markers expressed by the EVT in situ (Irving et al. 1995). Thus, the findings of expression of CSF-1 and c-fms mRNA and protein by these cells are consistent with previous in situ data.

Addition of exogenous CSF-1 to serum-starved EVT cell cultures stimulated their proliferation, similar to replenishment with FCS, indicating that CSF-1 is an important growth stimulatory molecule for these cells. The fact that both the CSF-1 neutralizing and c-fms receptor blocking $\mathrm{Ab}$ abolished this stimulation confirms the specificity of CSF-1 action and its mediation via the c-fms receptor. Furthermore, our demonstration that these $\mathrm{Ab}$ treatments reduce ${ }^{3} \mathrm{H}-\mathrm{TdR}$ incorporation to below control values (Fig. 4) indicates that these cells produce and respond to endogenous CSF-1. This notion was confirmed by immunofluorescence (Fig. 1) and RT-PCR (Fig. 2) experiments which showed that in vitro propagated invasive EVT cells stain positively for CSF-1 and c-fms protein and contain transcripts for CSF-1 and c-fms mRNA. Thus first trimester human EVT cells are equipped with an autocrine CSF-1 loop for growth stimulation. It is highly likely that a paracrine CSF-1 stimulation also occurs in situ, since glandular epithelium

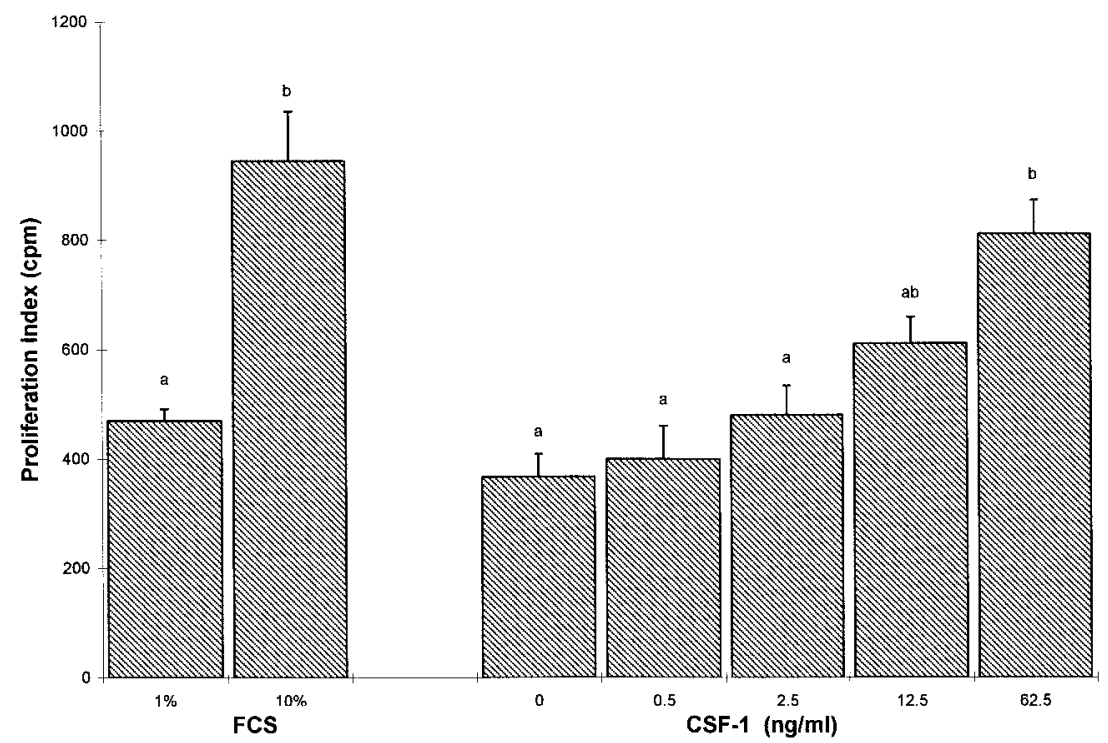

Figure 3 The effects of CSF- 1 on EVT cell proliferation. Increasing concentrations $(0-62 \cdot 5 \mathrm{ng} / \mathrm{ml})$ of CSF-1 produced a concentration-dependent increase in ${ }^{3} \mathrm{H}-\mathrm{TdR}$ incorporation. Treatment with $62.5 \mathrm{ng} / \mathrm{ml} \mathrm{CSF}-1$ stimulated proliferation to an extent approaching that of $10 \%$ FCS. Bars represent means ( \pm S.E.M.) of quadruplicate wells. Superscripts not sharing a common letter indicate significantly different ${ }^{3} \mathrm{H}-\mathrm{TdR}$ incorporation $(P<0 \cdot 05)$. 


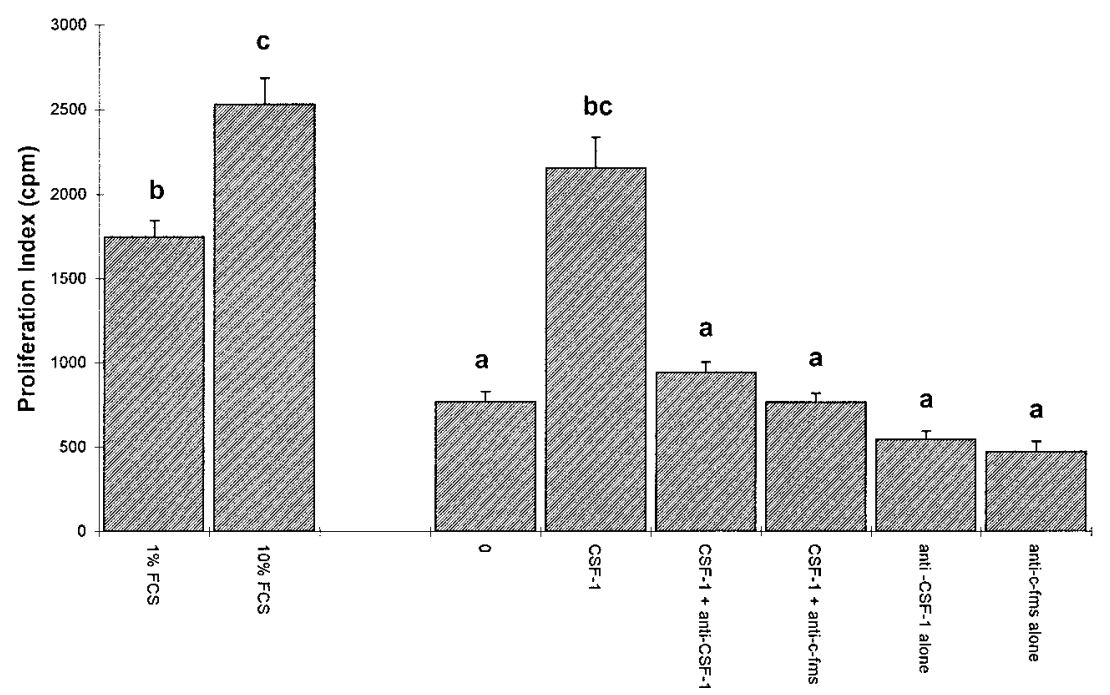

Figure 4 The effects of CSF-1, anti-CSF-1 and anti-c-fms Ab on EVT cell proliferation. Treatment with $20 \mathrm{ng} / \mathrm{ml} \mathrm{CSF-1} \mathrm{enhanced} \mathrm{proliferation} \mathrm{to} \mathrm{a} \mathrm{level} \mathrm{similar} \mathrm{to} 10 \%$ FCS (positive control). The CSF- 1 enhancement was abolished by c-fms blocking Ab $(25 \mu \mathrm{g} / \mathrm{ml})$ and reduced by anti CSF-1 neutralizing Ab $(25 \mu \mathrm{g} / \mathrm{ml})$. Bars represent means ( \pm S.E.M.) of quadruplicate wells. Superscripts not sharing a common letter indicate significantly different ${ }^{3} \mathrm{H}-\mathrm{TdR}$ incorporation $(P<0 \cdot 05)$.

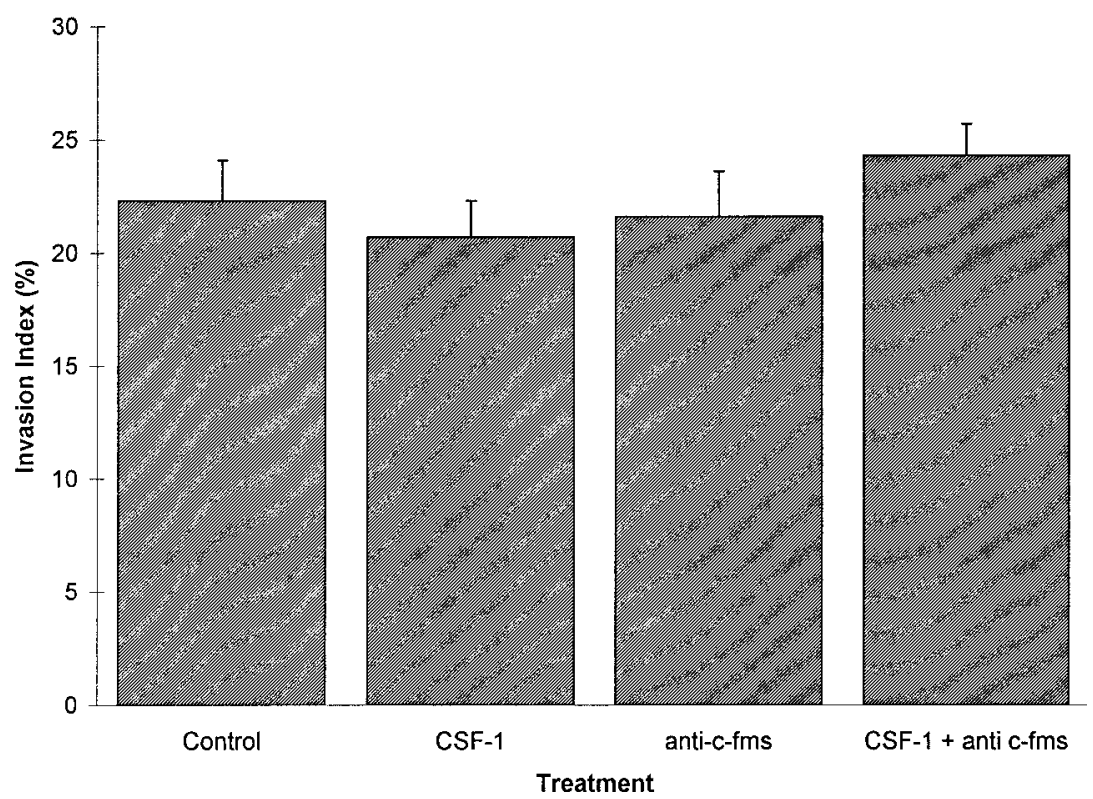

Figure 5 Results of a representative (out of three experiments using different EVT cell lines) 3-day Matrigel invasion assay with early passage first trimester EVT cells treated with CSF-1 $(10 \mathrm{ng} / \mathrm{ml})$ or untreated cells. No significant change in the invasiveness was observed in the presence of CSF-1. Bars represent means ( \pm S.E.M.) of triplicate wells.

of the pregnant uterus is a rich source of CSF-1 (Pollard et al. 1987).

Exogenous CSF-1 (even at higher dosage) had no effect on trophoblast cell invasiveness although a modest upregulation of MMP-2 and TIMP-1 mRNA was noted, indicating that there was no net shift in the balance between degradative enzyme and its inhibitor. Previous studies from our laboratory have described similar effects of two EGF-R ligands, EGF and TGF $\alpha$ on first trimester human EVT. Both these ligands stimulated trophoblast proliferation (Lysiak et al. 1993, 1994) but had no significant effect on invasion, even though they caused a 


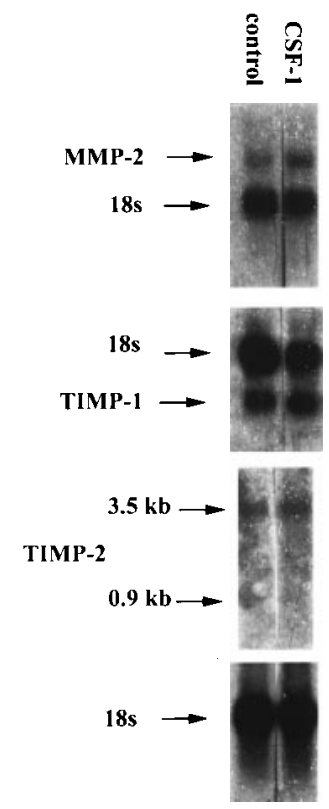

Figure 6 Northern autoradiograph of MMP-2, TIMP-1 and TIMP-2 mRNA expression in untreated and CSF-1 $(10 \mathrm{ng} / \mathrm{ml})$ treated EVT cells. 18S rRNA was included as RNA loading control. Densitometric measurements (not shown) after normalization for loading revealed a small (1.5) upregulation of MMP-2 as well as TIMP-1 mRNA following CSF-1 treatment.

balanced upregulation of both MMP-2 and TIMP-1 mRNAs (Lysiak et al. 1993). Another EGF-R ligand, amphiregulin, localized in situ to the early gestational syncytiotrophoblast, was also found to stimulate proliferation of invasive EVT cells in culture (Lysiak et al. 1995). We have recently established that two angiogenic growth factors, vascular endothelial growth factor (VEGF) (Athanassiades et al. 1998) and placenta growth factor (PIGF) (Athanassiades \& Lala 1998), produced at the fetal-maternal interface exert growth promoting actions on the EVT but no influence on their migratory or invasive functions. Thus there appears to be a redundancy in the number of locally derived growth factors which enhance EVT cell growth. In contrast to the pure growthstimulatory effects of CSF-1, EGF-R ligands, VEGF and PlGF, recent work in our laboratory has identified IGF-II as a molecule which stimulates trophoblast invasion without affecting its proliferation (Lala \& Lysiak 1994, Hamilton et al. 1998). The enhancement of invasion is, at least in part, accomplished through the ability of IGF-II to increase trophoblast migration (Irving \& Lala 1995), an essential step in invasion. Taken together, these results demonstrate that EVT cell proliferation and invasion are not linked, and can be under independent controls which can be exerted in autocrine as well as paracrine pathways.

While the present study was in progress, Lewis et al. (1996) reported results of a similar study using a SV40 large $\mathrm{T}$ antigen (Tag)-transformed immortal trophoblast cell line. Like the normal invasive first trimester EVT (reported in the present study), those cells also exhibited an autocrine CSF-1 loop which enhanced proliferation. Since SV40 Tag transformation of the trophoblast has been shown by our laboratory to induce a premalignant phenotype, inclusive of alterations in responses to certain proliferation and invasion regulating growth factors (Graham et al. 1993b, Khoo et al. 1998), the results of the present study provide important validation of the above reported results for normal EVT cell function.

\section{Acknowledgements}

This work was supported by a grant from the Medical Research Council of Canada to P K L and a fellowship of the Lalar Foundation, USA to G S H.

\section{References}

Athanassiades A \& Lala PK 1998 Role of placenta growth factor (PlGF) in human extravillous trophoblast proliferation, migration and invasiveness. Placenta (In Press).

Athanassiades A, Hamilton GS \& Lala PK 1998 Vascular endothelial growth factor stimulates proliferation but not migration or invasiveness in human extravillous trophoblast. Biology of Reproduction (In Press).

Bartocci A, Pollard JW \& Stanley ER 1986 Regulation of colony-stimulating factor-1 during pregnancy. Journal of Experimental Medicine 164 956-961.

Coussens L, VanBeveren C, Smith D, Chen E, Mitchell RL, Issacke CM, Verma IM \& Ullrich A 1986 Structural alteration of viral homologue of receptor proto-oncongene c-fms at carboxyl terminus. Nature 320 277-280.

Daiter E, Pampfer S, Yeung YG, Barad D, Stanley ER \& Pollard JW 1992 Expression of colony-stimulating factor-1 (CSF-1) in the human uterus and placenta. Journal of Clinical Endocrinology and Metabolism 74 850-858.

Graham CH \& Lala PK 1991 Mechanism of control of trophoblast invasion in situ. Journal of Cell Physiology 148 228-234.

Graham CH \& Lala PK 1992 Mechanisms of placental invasion of the uterus and their control. Biochemistry and Cell Biology 70 867-874.

Graham CH, Lysiak JJ, McCrae KR \& Lala PK 1992 Localization of transforming growth factor- $\beta$ at the human fetal-maternal interface: role in trophoblast growth and differentiation. Biology of Reproduction 46 561-572.

Graham CH, McCrae KR \& Lala PK 1993a Molecular mechanisms controlling trophoblast invasion of the uterus. Trophoblast Research 7 $237-250$.

Graham CH, Hawley TS, Hawley RG, MacDougall JR, Kerbel RS, Khoo N \& Lala PK 19936 Establishment and characterization of first trimester human trophoblast cells with extended lifespan. Experimental Cell Research 206 204-211.

Hamilton GS, Lysiak JJ, Han VKM \& Lala PK 1998 Autocrineparacrine regulation of human trophoblast invasiveness by insulin-like growth factor (IGF)-II and IGF binding protein (IGFBP)-1. Experimental Cell Research (In Press).

Irving JA \& Lala PK 1995 Functional role of cell surface integrins on human trophoblast cell migration: regulation by TGF $\beta$, IGF-II and IGFBP-1. Experimental Cell Research 217 419-427.

Irving JA, Lysiak JJ, Graham CH, Han VK, Hearn S \& Lala PK 1995 Characteristics of trophoblast cells migrating from first trimester chorionic villous explants and propagated in culture. Placenta 16 413-433. 
Jokhi PP, Chumbley G, King A, Gardner L \& Loke YW 1993 Expression of the colony-stimulating factor-1 receptor (c-fms product) by cells at the human uteroplacental interface. Laboratory Investigations 68 308-320.

Kauma SW, Aukerman SL, Eirman D \& Turner T 1991 Colony-stimulating factor-1 and c-fms expression in human endometrial tissues and placenta during the menstrual cycle and early pregnancy. Journal of Clinical Endocrinology and Metabolism $\mathbf{7 3}$ 746-751.

Khoo NKS, Bond SL, Bechberger JF \& Lala PK 1998 SV40 Tag transformation of the normal invasive trophoblast results in a premalignant phenotype. 1. Mechanisms responsible for hyperinvasiveness and resistance to antiinvasive action of TGF $\beta$. International Journal of Cancer 77 429-439.

Lala PK \& Lysiak JJ 1994 Role of locally produced growth factors in human placental growth and invasion with special reference to transforming growth factors. In Immunology of Reproduction, pp. 57-81. Ed JS Hunt. New York: Springer-Verlag.

Lala PK \& Hamilton GS 1996 Growth factors, proteases and protease inhibitors in the maternal-fetal dialogue. Placenta 17 546-555.

Lewis MP, Clement M, Takeda S, Kirby PL, Seki H, Lonsdale LB, Sullivan MH, Elder MG \& White JO 1996 Partial characterization of an immortalized human trophoblast cell-line, TLC-1, which possesses a CSF-1 autocrine loop. Placenta 17 137-146.

Lysiak JJ, Han VKM \& Lala PK 1993 Localization of transforming growth factor (TGF)- $\alpha$ in the human placenta and decidua: role in trophoblast growth. Biology of Reproduction 49 885-894.

Lysiak JJ, Connelly IH, Khoo NKS, Stetler-Stevenson W \& Lala PK 1994 Role of transforming growth factor (TGF)- $\alpha$ and epidermal growth factor (EGF) on proliferation and invasion by first trimester human trophoblast. Trophoblast Research 8 455-467.
Lysiak JJ, Johnson GR \& Lala PK 1995 Localization of amphiregulin in the human placenta and decidua throughout gestation: role in trophoblast growth. Placenta 16 359-366.

Pampfer S, Daiter E, Baird D \& Pollard JW 1992 Expression of the colony-stimulating factor-1 (c-fms proto-oncogene product) in the human uterus and placenta. Biology of Reproduction 46 48-57.

Pollard JW, Bartocci A, Arececi R, Orlofsky A, Ladner MB \& Stanley ER 1987 Apparent role of the macrophage growth factor CSF-1 in placental development. Nature 330 484-486.

Repesh LA 1989 A new in vitro assay for quantitating tumour cell invasion. Invasion and Metastasis 9 192-208.

Saji F, Azuma C, Kimura T, Koyama M, Ohashi K \& Tanizawa O 1990 Gene expression of macrophage colony stimulating factor and its receptor in human placenta and decidua. American Journal of Reproductive Immunology 24 99-104.

Sherr CJ \& Stanley ER 1990 Colony-stimulating factor-1 (macrophage colony stimulating-factor). In Peptide Growth Factors and their Receptors, I, pp 667-698. Eds MB Sporn \& AB Roberts. New York: Springer-Verlag.

Stanley ER, Guilbert LJ, Tushinski RJ, Bartelmez SH 1983 CSF-1: a mononuclear phagocyte lineage-specific hemopoeitic growth factor. Journal of Cell Biochemistry 21 151-159.

Stetler-Stevenson WG, Krutzach HL \& Liotta LA 1989 Tissue inhibitor of metalloproteinases (TIMP-2). Journal of Biological Chemistry $26417372-17378$

Received 24 February 1998

Accepted 18 May 1998 